\title{
Optical properties and electronic structure of copper-manganese solid solutions
}

\author{
V.M.Bondar, V.S.Stashchuk, O.P.Polianska, \\ Ie.O.Chernukha, B.A.Tsuk
}

\author{
T.Shevchenko Kyiv National University, Physics Department, \\ Chair of Optics, 64 Volodymyrska St., 01601 Kyiv, Ukraine
}

\section{Received April 01, 2013}

\begin{abstract}
Optical properties of Cu-Mn alloys with Mn concentrations of $2 \%, 5 \%, 10 \%$ and $17.5 \%$ (which corresponds to $\gamma$-solid solutions) were studied in a wide spectral range of $0.23-2.8 \mu \mathrm{m}(0.44-5.39 \mathrm{eV})$. Real and imaginary parts of the refractive index were measured and other optical properties such as dielectric constant, optical conductivity and the coefficient of specular reflectance at normal incidence were calculated based on them. Based on the analysis of the dispersion dependences $\varepsilon(h v), R(h v)$ and $\sigma(h v)$ the electronic structure model of these alloys was proposed. According to this model, the electronic spectra (dependence of the density of electronic states on energy $N(E)$ ) of alloys with the indicated concentrations of components are the superposition of electronic spectra of $\mathrm{Cu}$ host, with weights equal to $\mathrm{Cu}$ concentrations, and the density of states within the impurity band, calculated basing on the experimental data.
\end{abstract}

Изучены оптические свойства сплавов $\mathrm{Cu}-\mathrm{Mn}$ с концентрациями $2,5,10$ и $17.5 \% \mathrm{Mn}$, соответствующими $\gamma$-твердым растворам, в широкой области спектра $0,23-2,8$ мкм $(0,44-$ 5,39 эВ), путем измерения действительной и мнимой части показателя преломления. На их основе рассчитаны другие оптические характеристики, такие как диэлектрическая проницаемость, оптическая проводимость и коэффициент зеркального отражения при нормальном падении света. Путем анализа дисперсионных зависимостей $\varepsilon(h v), R(h v)$ и $\sigma(h v)$ предложена модель электронной структуры указанных сплавов. Согласно этой модели, әлектронный спектр сплавов $\mathrm{Cu}-\mathrm{Mn}$, зависимость плотности электронных состояний от энергии $N(E)$, представляет собой суперпозицию электронных спектров основы $(\mathrm{Cu}) \mathrm{c}$ пропорциями, равными концентрациям $\mathrm{Cu}$ в сплавах, и плотности состояний в пределах примесной зоны, рассчитанной на основе полученных экспериментальных данных.

Оптичні властивості та електронна структура твердих розчинів мідь-марганещь. В.М.Бондар, В.С.Сташук, О.П.Полянська, Є.О.Чернуха, Б.А.Цюк.

Вивчено оптичні властивості сплавів $\mathrm{Cu}-\mathrm{Mn} 3$ концентраціями 2, 5, 10 та 17,5\% $\mathrm{Mn}$, що відповідають $\gamma$-твердим розчинам, в широкій області спектра 0,23-2,8 мкм $(0,44-5,39$ еВ) шляхом вимірювання дійсної та уявної частини показника заломлення, на основі яких розраховано інші оптичні характеристики, такі як діелектрична проникність, оптична провідність та коефіцієнт дзеркального відбивання при нормальному падінні світла. Шляхом аналізу дисперсійних залежностей $\varepsilon(h v), R(h v)$ та $\sigma(h v)$ запропоновано модель електронної структури вказаних сплавів. Згідно цієї моделі, електронний спектр (залежність густини електронних станів від енергії $N(E)$ ) сплавів з вказаними концентраціями компонентів являє собою суперпозицію електронних спектрів основи $(\mathrm{Cu})$ з пропорціями, що дорівнюють концентраціям Сu у сплавах, та густини станів у межах домішкової зони, розрахованої на основі отриманих експериментальних даних. 


\section{Introduction}

$\mathrm{Cu}-\mathrm{Mn}$ alloys, unlike $\mathrm{Cu}-\mathrm{Ni}$ alloys, which are single-phase [1] in a wide range of concentrations, form two-phase solid solutions with $\gamma$-phase $\mathrm{Cu}$ and $\varepsilon$-phase $\mathrm{Mn}$. At the same time, other transition metals such as $\mathrm{Fe}$, Co or $\mathrm{Cr}$ are almost insoluble in $\mathrm{Cu}$ [2]. On the other hand it is well known that the impurities of $3 d$-transition metals in noble metals, in particular $\mathrm{Cu}$, form localized magnetic moments [3], which gave impetus to theoretical studies of electronic properties of the compounds of noble metals, in particular $\mathrm{Cu}$, with $3 d$-transition metals [4]. It was found that with addition of $3 d$-transition metals to noble metals, especially to copper, impurity bands form in the electronic spectrum of the solvent, located below the Fermi level $E_{F}$ [5]. This enabled to determine the parameters that characterize the impurity band as in the case of alloys $\mathrm{Cu}-\mathrm{Fe}$ [6], $\mathrm{Cu}-\mathrm{Co}$ [7] and $\mathrm{Cu}-\mathrm{Cr}$ [8]. However, so far, to our knowledge, optical properties of alloys of copper with another $3 d$-transition metal (antiferromagnetic $\mathrm{Mn}$ ) were not studied. Therefore in this work we studied the optical properties and, based on them, the electronic structure of $\mathrm{Cu}-\mathrm{Mn}$ compounds, rich in $\mathrm{Cu}$.

\section{Experimental}

Optical properties of solid solutions of $\mathrm{Cu}-\mathrm{Mn}$ with $\mathrm{Mn}$ concentrations of $2 \%$, $5 \%, 10 \%$ and $17.5 \%$, and pure $\mathrm{Cu}$ and $\mathrm{Mn}$ were investigated in the spectral range $\lambda=0.23-2.8 \mu \mathrm{m} \quad(h v=0.44-5.39 \quad \mathrm{eV}) \quad$ by Beattie ellipsometric method using an original spectral ellipsometer [9]. The ellipsometer included the following functional units: block of light sources, consisting of deuterium-mercury lamp ART-250, hydrogen lamp ICE-25 and halogen lamp KGM-150; block of radiation detectors, which included photoelectron multipliers PEM-39A and PEM-62; G-5 goniometer, which housed the Glan prism polarizer $\mathrm{P}$ and analyzer $\mathrm{A}$. The studied samples were located on the goniometer sample stage. The setup also included electrical components for amplifying electrical signals and their registration by standard digital voltmeters and a PC. Ellipsometric parameters $\Delta$ (phase shift between $p$-and $s$-polarization components) and $\psi$ (azimuth of the restored linear polarization) were measured within this setup in the specified spectral range at a fixed angle of incidence close to the principal. Based on $\Delta$

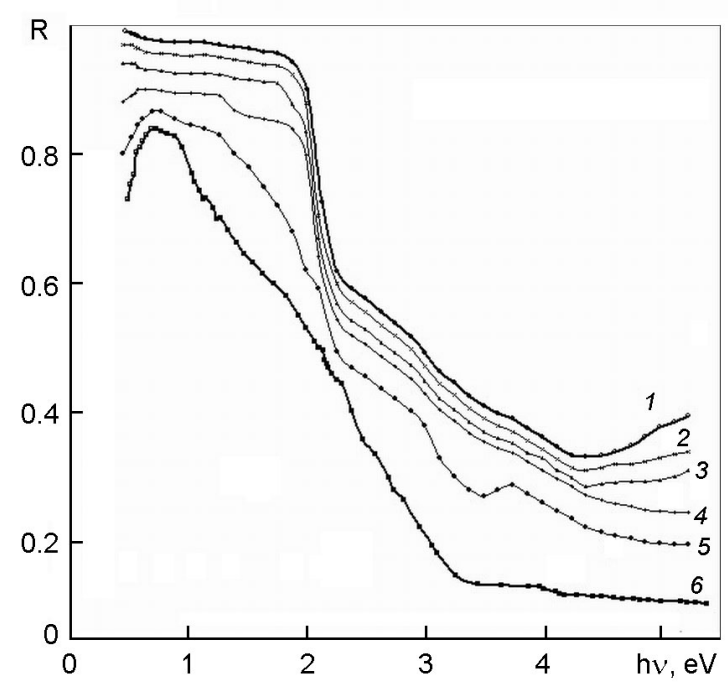

Fig. 1. Dispersion curves of reflectance $R(h v)$ for $\mathrm{Cu}(1), \mathrm{Mn}(6)$ and their alloys containing $2 \%$ (2), $5 \%$ (3), $10 \%(4)$ and $17.5 \%$ Mn (5).

and $\psi$ the refraction and absorption indices $n$ and $\chi$ were calculated, and then the dielectric constant $\varepsilon=n^{2}-\chi^{2}$, optical conductivity $\sigma=4 \pi \varepsilon_{0} n \chi \nu \quad(\nu-$ light frequency) and the reflection coefficient at normal incidence $R=(n-1)^{2}+\chi^{2} /(n+1)^{2}+\chi^{2} \quad$ were obtained.

$\mathrm{Cu}-\mathrm{Mn}$ alloy samples were obtained by vacuum-arc melting of pure $\mathrm{Cu}$ and $\mathrm{Mn}$ with corresponding weights in argon atmosphere by repeated melting. To achieve greater uniformity the samples were annealed in the same atmosphere at $900^{\circ} \mathrm{C}$ for $24 \mathrm{~h}$. Sample mirror surfaces were prepared by mechanical grinding and polishing with diamond paste with subsequent recrystallization annealing and electropolishing. X-ray structure and phase analysis of the alloy samples was also conducted with DRON-3.0 X-ray diffractometer.

\section{Results and discussion}

Analysis of optical properties dependence on photon energy $h v$ in the investigated spectral range $h v=0.44-5.39 \mathrm{eV}$ provides information about changes in the electronic structure of $\mathrm{Cu}$ with the addition of $\mathrm{Mn}$. First we consider the dispersion curves of reflection coefficient $R(h v)$ of studied $\mathrm{Cu}-$ $\mathrm{Mn}$ alloys and pure $\mathrm{Cu}$ and $\mathrm{Mn}$, shown in Fig. 1 . The figure shows that the reflection curve $R(h v)$ for pure $\mathrm{Cu}$ is a smooth curve without any anomalies, although the value of $R$ varies within wide limits (35-99\%), except for the shallow minimum located at 


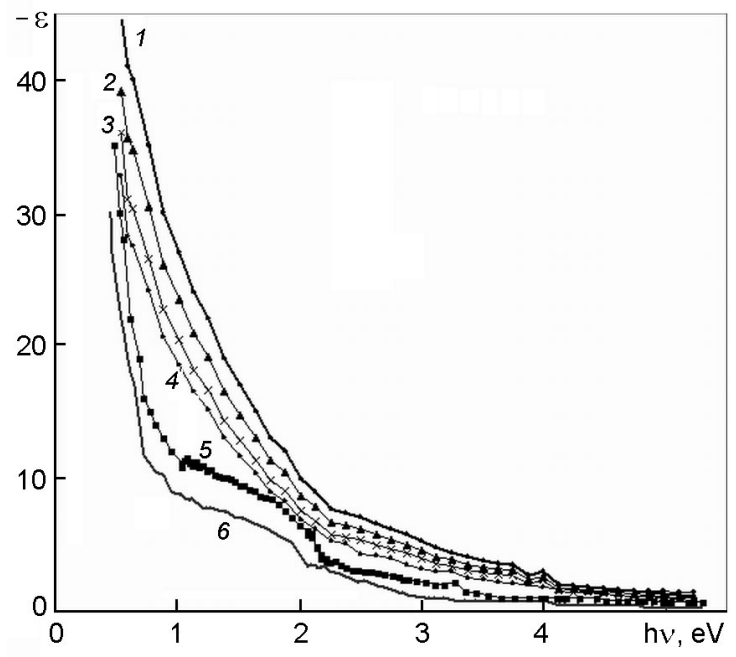

Fig. 2. Dispersion curves of dielectric permittivity $\varepsilon(h v)$ for pure $\mathrm{Cu}(1)$ and $\mathrm{Mn}(6)$, and Cu-Mn alloys containing $2 \%$ (2), $5 \%$ (3), $10 \%(4)$ and $17.5 \% \mathrm{Mn}(5)$.

about $4.2 \mathrm{eV}$, caused by electron interband transitions. At the same time, the value of $R$ for $\mathrm{Mn}$ is much smaller than that for $\mathrm{Cu}$, especially in ultraviolet region, where the values of $R$ differ by almost 3.5 times. A broad maximum is observed in infrared region $(h v<1.1 \mathrm{eV})$ for $\mathrm{Mn}$, located at about $0.95 \mathrm{eV}$. It is seen that in this area $R$ value for $\mathrm{Cu}$ depends weakly on energy, indicating the dominance of interband electron transitions. With the addition of $\mathrm{Mn}$ the value of $R$ in the ultraviolet spectral region ( $h n u>3.0 \mathrm{eV}$ ) decreases with the increase of $\mathrm{Mn}$ concentration, and a minimum at $4.2 \mathrm{eV}$, characteristic for pure $\mathrm{Cu}$, does not appear on $R(h \mathrm{v})$ curves of alloys with $\mathrm{Mn}$ concentrations higher than $10 \%$. The behavior of the curve $R(h v)$ for $\mathrm{Cu}-17.5 \%$ $\mathrm{Mn}$ alloy is quite peculiar, as a maximum at $3.85 \mathrm{eV}$ clearly appears on the curve, which is virtually absent in other alloys. It is speculated that with further increase of manganese concentration this maximum intensity will increase, as it is observed on the $R(h v)$ curve of pure manganese. Therefore, the most significant changes in the $\operatorname{IR}(h v)$ spectra of the alloys are observed in infrared region (with $h v<1.5 \mathrm{eV}$ ), which indicates the increasing role of interband transitions with the increase of manganese concentrations.

Next we proceed to analyze the dispersion of dielectric constant $\varepsilon(h v)$, shown in Fig. 2. The figure shows that $\varepsilon(h v)$ curves for the alloys with low Mn content are simi-

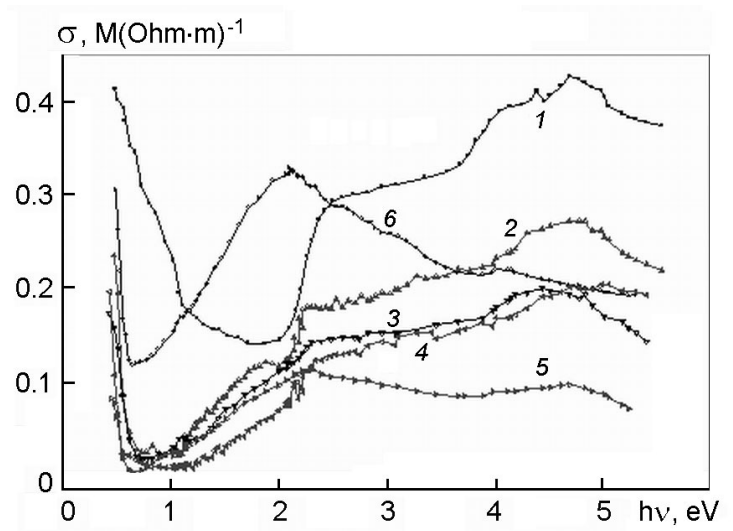

Fig. 3. Dispersion curves of interband optical conductivity $\sigma(h v)$ for pure $\mathrm{Cu}(1)$ and $\mathrm{Mn}(2)$ and $\mathrm{Cu}-\mathrm{Mn}$ alloys containing $2 \%(3), 5 \%$ (4), $10 \%(5)$ and $17.5 \% \mathrm{Mn}(6)$. Curves (1) and (2) for the pure component raised by $0.1 \mathrm{M}(\mathrm{Ohm} \cdot \mathrm{m})^{-1}$.

lar to pure copper $\varepsilon(h v)$ curve, which decreases monotonically with the decrease in energy, which is typical for normal dispersion. In samples with high $\mathrm{Mn}$ concentrations, as well as for pure $\mathrm{Mn}$, anomalous dispersion is observed on $\varepsilon(h v)$ curves at 1.0-3.0 eV, indicating the dominance of interband electron transitions in this spectral range. Additional information can be obtained by analyzing the $\varepsilon(h v)$ curves at $h v=$ $3.3-4.5 \mathrm{eV}$, where the value of $\varepsilon$ for all studied alloys is close to zero, which is a necessary condition for the excitation of plasma oscillations.

Next, let's look more detailed at the dispersion of optical conductivity $\sigma(h v)$, which is proportional to the interband density of electronic states $G(h v)$ [10]. Experimental $\sigma(h v)$ curves of investigated alloys and pure $\mathrm{Cu}$ and $\mathrm{Mn}$ are shown in Fig. 3. The features of $\sigma(h v)$ spectra of pure $\mathrm{Cu}$ and $\mathrm{Mn}$ are significantly different. At energies $h v<1.5 \mathrm{eV}$ the optical conductivity value of $\mathrm{Cu}$ increases monotonically with the decrease of energy $h v$, which indicates the dominance of intraband transitions that occur within each of the bands that cross the Fermi level $E_{F}$. Characteristic features of $\sigma(h v)$ spectrum of Cu are a sharp interband absorption edge at $h v=2.1-2.3 \mathrm{eV}$, centered at $2.2 \mathrm{eV}$, and an intense absorption band with a maximum near $4.72 \mathrm{eV}$, as well as minor spectrum features at 3.5$4.4 \mathrm{eV} . \sigma(h v)$ curve of $\mathrm{Mn}$ is in turn characterized by a wide maximum at $2.2 \mathrm{eV}$ and a 
slight increase in $\sigma$ value in the IR range $(h v<0.5 \mathrm{eV})$ caused by intraband electron transitions. Next we analyze the dispersion of optical conductivity $\sigma(h v)$ of Cu-Mn alloys with the increase of $\mathrm{Mn}$ concentration (Fig. 3).

The figure shows that an addition of low quantities of manganese to copper does not introduce significant changes in the overall shape of the absorption spectrum of copper. Characteristic features of $\sigma(h v)$ spectrum of pure copper, in particular a short peak at $4.72 \mathrm{eV}$ and a sharp edge at $2.1-2.3 \mathrm{eV}$, to some extent, appear in all of the investigated $\mathrm{Cu}-\mathrm{Mn}$ alloys, as in $\mathrm{Cu}-\mathrm{Co}$ alloys [7]. It is found that peak at $4.72 \mathrm{eV}$ is observed in all alloys, hardly shifting along the energy scale. The sharp absorption edge at $2.2 \mathrm{eV}$ appears only in the samples with manganese concentration below $10 \%$. At the same time, in infrared spectral range $h v=0.8-1.8 \mathrm{eV}$ it is found that with addition of only $2 \% \mathrm{Mn}$ to $\mathrm{Cu}$ the contribution of "free" electrons in the overall absorption decreases sharply. At high concentrations of $\mathrm{Mn}$ this spectral area is completely dominated by interband electron transitions. This is due to the sharp increase of relaxation frequency of electrons in the alloys as compared to the pure components. It is found that the addition of $\mathrm{Mn}$ to $\mathrm{Cu}$ at $\mathrm{Mn}$ concentrations greater than $5 \%$ gives a very strong effect - the appearance of an intense absorption band on the $\sigma(h v)$ curves in the near-IR range with a peak at $h \mathrm{v}=$ 1.9-2.0 eV. Fig. 3 shows that a minimum is observed on $\mathrm{Cu} \sigma(h v)$ curve in this region, while the maximum of absorption of pure $\mathrm{Mn}$, according to our experimental data, is located at $2.2 \mathrm{eV}$. Consequently this band is not associated with pure $\mathrm{Cu}$ and $\mathrm{Mn}$, and it is most likely associated with the resonant states arising in the electronic spectrum of $\mathrm{Cu}$ by addition of $\mathrm{Mn}$. The maximum, which is located at $2.5 \mathrm{eV}$ for the $\mathrm{Cu}-2 \% \mathrm{Mn}$ alloy, shifts in high-energy region of the spectrum, for example, for $\mathrm{Cu}-17.5 \% \mathrm{Mn}$ alloy it is located at $2.15 \mathrm{eV}$ (see Fig. 3). Clearly, the formation of additional band in the alloys is due to the changes in the electronic spectra of $\mathrm{Cu}-\mathrm{Mn}$ alloys. These changes are associated with the restructuring of the energy spectrum of $\mathrm{Cu}$ and the appearance, as noted above, of resonant impurity states [10].

Further we analyze the dispersion curves of the residual optical conductivity $\Delta \sigma(h v)$, which represents the difference between the

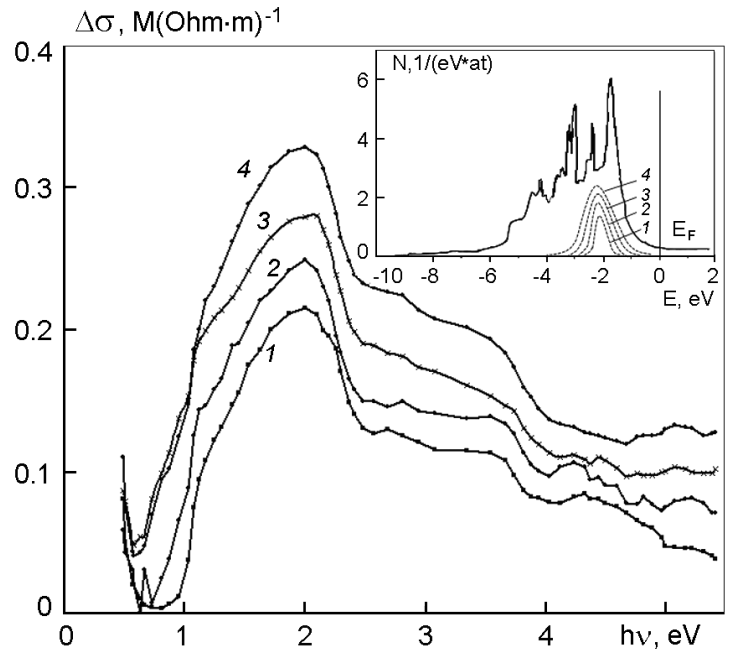

Fig. 4. Dispersion of residual optical conductivity $\Delta \sigma(h v)$ for $\mathrm{Cu}-\mathrm{Mn}$ alloys containing $2 \%$ (1), $5 \%$ (2) $10 \%$ (3) and $17.5 \% \mathrm{Mn}$ (4). All curves are shifted upwards by $0.1 \mathrm{M}(\mathrm{Ohm} \cdot \mathrm{m})^{-1}$. Inset are the density of states $N(E)$ curves for $\mathrm{Cu}$ [11] and $\mathrm{Cu}-\mathrm{Mn}$ alloys within the impurity band (dashed lines).

experimental values $\sigma(h v)$ for the alloys and the values of the optical conductivity of pure copper $\sigma_{\mathrm{Cu}}(h v)$ and pure manganese $\sigma_{\mathrm{Mn}}(h v)$ with respective weights $\Delta \sigma(h v)=$ $\sigma(h v)-(1-c) \sigma_{\mathrm{Cu}}(h v)+c \sigma_{\mathrm{Mn}}(h v)(c-$ the concentration of $\mathrm{Mn}$ ), which for $\mathrm{Cu}-\mathrm{Mn}$ alloys containing $2 \%, 5 \%, 10 \%$, and $17.5 \%$ are shown in Fig. 4.

It is seen that for all investigated alloys a new absorption band with the maximum at 2.05-2.15 eV appears. From the obtained data, presented in Fig. 3 and Fig. 4 the following conclusions can be made: firstly, at low concentrations of $\mathrm{Mn}(5 \%)$ it solves almost completely in $\mathrm{Cu}$, secondly, the solubility increases with the increase of $\mathrm{Mn}$ concentration, and thirdly, an impurity $d$-band forms in the electronic spectrum of $\mathrm{Cu}-\mathrm{Mn}$ solid solution, associated with $\mathrm{Mn}$, which is located at 2.05-2.15 eV below the Fermi level $E_{F}$.

Given the results of studies of the electronic structure of pure copper and its optical spectrum [12], we can propose a model of the electronic structure of $\mathrm{Cu}-\mathrm{Mn}$ solid solutions. According to [12], the absorption edge in pure copper at $2.1-2.2 \mathrm{eV}$ is associated with transitions of electrons from the peaks of $d$-band near the $L_{3}$ Brillouin zone (BZ) to free states of $s-p$-bands $L_{2}^{\prime}$ in the vicinity of the Fermi level (FL) $E_{F}$. Based on the data of the experimental study of 
optical properties of $\mathrm{Cu}-\mathrm{Mn}$ alloys it can be concluded that the energy gap between the top of $d$-Cu bands and the Fermi level with addition of $\mathrm{Mn}$ remains unchanged. That is, the position of $d$-band relative to the Fermi level is virtually unchanged in the electronic spectrum of the alloys. Intense interband absorption is observed above the absorption edge, which is associated with transitions in the large volume of BZ from 2nd, 3rd and 4th bands into the free states of sixth band in $L-W$ and $D-X$ directions of the Brillouin zone [10]. Taking into account that the high-energy peak on the $\sigma(h v)$ curve of copper at $4.7 \mathrm{eV}$ is related to transitions from the sixth to the seventh band, mainly from $d$-states of $L_{1}$ to free $s p$-band levels of $L_{2}^{\prime}$ [11], one arrives to conclusion that the structure of $d$-bands located at $4.0-4.95 \mathrm{eV}$ lower than the Fermi level is not changed in the alloys and it is similar to the $d$-bands of copper. Thus, the energy bands in the investigated $\mathrm{Cu}-\mathrm{Mn}$ alloys retain the characteristics of the electron spectrum of pure copper.

Assuming by analogy with $\mathrm{Cu}-\mathrm{Fe}$ and $\mathrm{Cu}-\mathrm{Cr}$ alloys $[6,8]$ that the absorption band with a peak at $2 \mathrm{eV}$ in the $\sigma(h v)$ optical spectra is related to electron transitions from the impurity $d$-subband to free electron states in a vicinity of the Fermi level $E_{F}$ and using the obtained data, one can find a distance of the energy center of the impurity band from the Fermi level $E_{d}-E_{F}$ as well as its half-width $\Delta$. According to the experimental data in $\mathrm{Cu}-\mathrm{Mn}$ solid solution the value of $E_{d}-E_{F}$ is about $2.1 \mathrm{eV}$ and almost independent on the concentration of $\mathrm{Mn}$, and $\Delta$ increases slightly with increasing $\mathrm{Mn}$ content in the solution and equals $1.35 \mathrm{eV}(\mathrm{Cu}-2 \% \mathrm{Mn}), 1.4 \mathrm{eV}$ (Cu-17.5\% Mn). Based on the obtained $E_{d}-E_{F}$ density of electronic states $N(E)$ was calculated for $\mathrm{Cu}-\mathrm{Mn}$ alloys within the impurity band, shown on the inset in Fig. 4. Consequently, the resulting electron spectrum of any alloy is a superposition of the spectrum of pure copper with a weight equal to the concentration of $\mathrm{Cu}$ in the alloy, and the density of states of the alloy within the impurity band.

\section{Conclusions}

It was found that the new impurity energy band forms in the electronic spectrum of $\mathrm{Cu}$ with addition of antiferromagnetic $\mathrm{Mn}$ impurities, located approximately $2.1 \mathrm{eV}$ below the Fermi level $E_{F}$, which may split into two energy subbands due to exchange interaction. It was shown that the electron spectra $N(E)$ of $\mathrm{Cu}-\mathrm{Mn}$ alloys are, in a rough approximation, the superposition of densities of electronic states $N(E)$ of pure copper with a weight equal to its concentration in the alloy, and the density of states within the impurity band.

It was revealed that the optical properties of $\mathrm{Cu}-\mathrm{Mn}$ alloys are determined by solvent $(\mathrm{Cu}) d$-bands and impurity bands $(\mathrm{Mn})$. Due to interband transitions from the solvent $d$-band to its $s p$-band, the main absorption band in the $\sigma(h v)$ spectra of $\mathrm{Cu}-\mathrm{Mn}$ alloys is formed. Additional bands appear due to transitions of electrons from the impurity band to the Fermi level $E_{F}$.

\section{References}

1. Y.Kawazoe, T.Masumoto, K.Suzuki, A.Inoue, Condens. Matt., 37, 158 (1997).

2. A.K.Ahuja, S.Auluck, S.K.Joshi, Phys.Stat. Sol., 18, 105 (1983).

3. D.P.Norton, D.K.Freenstra, G.W.Ownby, Appl. Phys. Lett., 79, 352 (2001).

4. C.Cantoni, D.K.Christen, E.D.Specht, Supercond. Sci.Techn., 17, 341 (2004).

5. D.R.Penn, Phys. Rev.Lett., 42, 421 (1999).

6. A.E.Doroshenko, V.S.Stashchuk, S.N.Tkachenko, Phys. Met., 4, 830 (1986).

7. V.S.Stashchuk, Bullet Kiev University, 4, 401 (1997).

8. V.S.Stashchuk, Ukr.Fiz. Zh., 43, 282 (1996).

9. H.Fujiwara, Spectroscopic Ellipsometry Principles and Applications, Atrium. Wiley (2007).

10. L.V.Poperenko, V.S.Stashcuk, I.A.Shaikevych, V.A.Odarych, Diagnostics of Surface with Polarized Light, Kyiv University, Kyiv (2007) [in Ukrainian].

11. Y.Kakehashi, M.Atiqur R.Patoary, T.Tamashiro, Phys.Rev. B, 81, 245133 (2010).

12. M.N.Yasinska, V.S.Stashchuk, Appl.Spectr., 44, 634 (1996). 